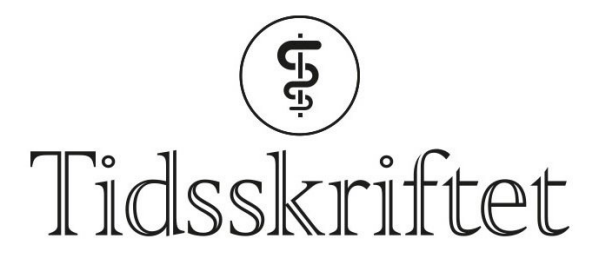

DEN NORSKE LEGEFORENING

\title{
Yngst i klassen, mer deprimert?
}

FRA ANDRE TIDSSKRIFTER

LISE SKOGSTAD LOFTSGAARD

Tidsskriftet

Er det en sammenheng mellom alder i årskullet og psykisk lidelse? En ny studie fra USA tyder på det.

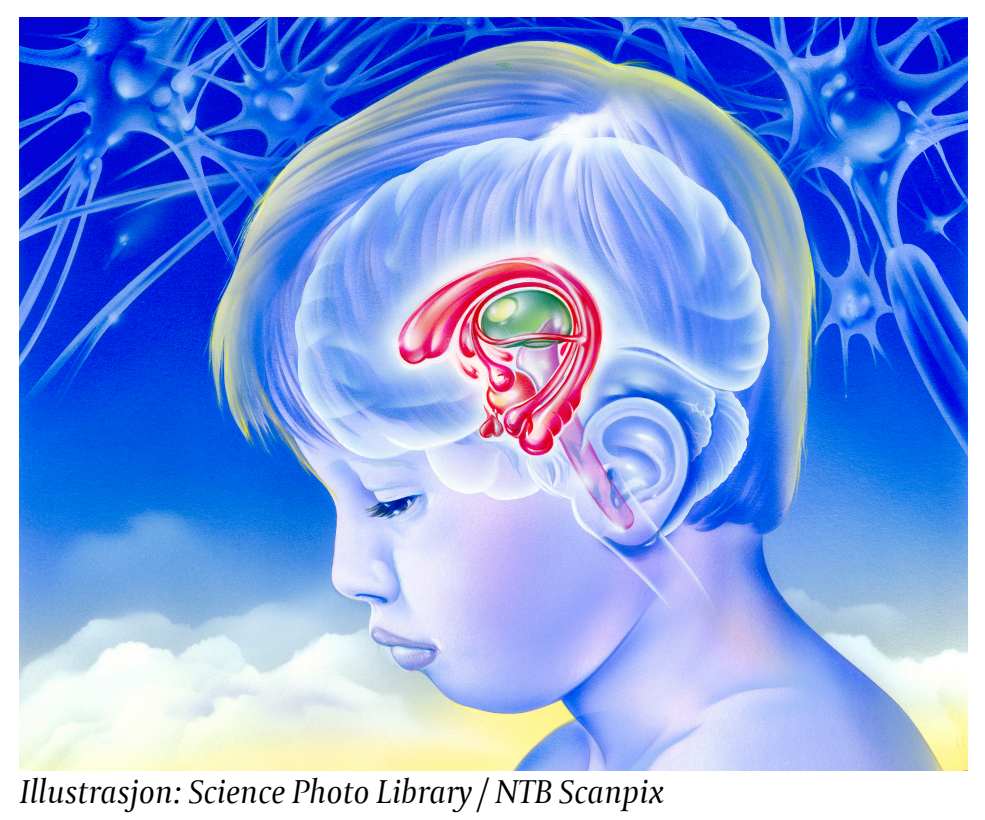

Flere tidligere studier har vist at barn født sent på året oftere får en ADHD-diagnose og at de presterer dårligere på skolen. Tidsskriftet JAMA Pediatrics publiserte nylig en kohortstudie som underst $ø$ tter disse funnene, og som i tillegg finner mer depresjon hos de yngste (1).

Kohortstudien analyserte data om flere enn en million barn i alderen 4-15 år og så på sammenhengen mellom relativ alder og insidens av psykisk utviklingshemning, ADHD og depresjon før fylte 16 år. Man delte inn barna i hvert årskull i fire grupper etter fødselsmåned, og gruppen med de eldste barna i klassen ble brukt som referanse. Forekomsten av alle de nevnte diagnosene $\varnothing$ kte gradvis og var høyest blant de yngste barna i klassen. For eksempel var justert hasardratio for depresjon 1,31 (95\% KI; 1,08-1,59) for den yngste gruppen sammenliknet med den eldste.

- Det nye ved denne studien er at den viser at de yngste i årskullet også har økt risiko for depresjon, sier Pål Surén, som er forsker ved Avdeling for barns helse og utvikling, Folkehelseinstituttet.

- Dette er overraskende, ettersom man i utgangspunktet ikke skulle tro at depresjon hadde 
så mye med relativ modenhet å gjøre. Det indikerer at det også er emosjonelle belastninger forbundet med det å være yngst i sitt årskull.

Forskerne bak studien foreslår blant annet å åpne for mer fleksibel skolestart for de yngste barna i et årskull. Dette har også vært diskutert i Norge i forbindelse med utredningen av hvorfor gutter gjør det dårligere i skolesystemet enn jenter. Forskerne advarer mot overdiagnostikk og understreker hvor viktig det er å ha et skolesystem som tar godt vare på de mest umodne barna.

\section{LITTERATUR:}

1. Root A, Brown JP, Forbes HJ et al. Association of relative age in the school year with diagnosis of intellectual disability, attention-deficit/hyperactivity. JAMA Pediatr 2019; doi: 10.1001/jamapediatrics.2019.3194. [PubMed][CrossRef]

Publisert: 6. november 2019. Tidsskr Nor Legeforen. DOI: 10.4045/tidsskr.19.0655

(C) Tidsskrift for Den norske legeforening 2020. Lastet ned fra tidsskriftet.no 